\title{
THE PANDEMIC OF FAKE NEWS AND DISINFORMATION IN THE AGE OF DEGLOBALIZATION
}

\section{Goran ZENDELOVSKI ${ }^{39}$ \\ Sergej CVETKOVSKI ${ }^{40}$}

Faculty of Philosophy - Institute for Security, Defence and Peace, Skopje

\begin{abstract}
In recent decades, globalization has distributed information and technological power around the world.This aspect of globalization has given rise to interdependence and an integration process that has united all into one global network and virtual space, contributing to the mutual inclusion and mixing of local and national with global. The power of modern information and communication technology and mass media has proven to be a superior "mass weapon" and an instrument of modern organization and coordination of activities in many aspects.

The achievements in the information and technological aspects of globalization have led to substantial changes in the concepts of national and international security.Internet access has opened the "doors" of individuals, organizations and countries to a global audience. Such openness to the world for many countries, instead of a chance, posed a threat to national security. As a powerful weapon, sophisticated technologies are used simultaneously, both to encourage and to prevent structural change and activity in states and societies.Before and after the outbreak of the coronavirus COVID-19 pandemic, the mass media and social networks played a significant role in the disseminating of information and presenting the situation regarding political and economic events in the world, international security and public health. But during the pandemic crisis, the media space gained importance and was used as a means of sharing fake news and disinformation that contributed to distorting the image of reality and real events in countries and the world.
\end{abstract}

Key words: fake news, disinformation, mass media, deglobalization, insecurity.

\section{Introduction}

At the beginning of the third decade of the 21st century, we have a number of reasons to look at the international security situation in more detail, and to try to answer questions about what has changed in terms of security, what is the new security environment in which we live, because despite the civilization and scientific-technological development, the existential problems are still not solved. From a security point of view, the complexity stems from the fact that today's world is characterized by rapid and dynamic changes which brings new and often unpredictable risks and threats to the security of states and the international order.

\footnotetext{
${ }^{39}$ Contact address: zendelovski@fzf.ukim.edu.mk

${ }^{40}$ Contact address: sergej@fzf.ukim.edu.mk
} 
The forces that fueled the change arose from the dynamics of modern globalization, which received the epithet of a dangerous and unpredictable phenomenon that contributed to the transfer of security from the military to the non-military sphere.

For many, it is inconceivable that the processes of globalization should be completely stopped, although certain events and happenings may affect its dynamics. In this context, Roland Robertson points out that the processes of globalization are impossible to stop, but it is possible to slow down through the process of glocalization that prevents a complete homogenizing effect of globalization (Robertson and White, 2007). In addition to glocalization, as a threat to the processes of globalization, these can be other different events and crises that have a global scale, such as: regional conflict or world war, macroterrorist attacks, financial crises, climate change and natural disasters (hurricanes, tsunamis, earthquakes), weapons of mass destruction, nuclear disasters (Chernobyl, Fukushima), scientific and technological advances (anti-missile shield, space technology, cyber-attacks), pandemics (AIDS, influenza, Ebola, the coronavirus COVID - 19). Due to the consequences of these dangers, many countries can take restrictive measures and activities in self-defense that include various protectionist policies and controls on the flow of capital, services, people and technologies. In this way, countries can influence the dynamics of globalization and destabilize its processes. This creates a process of deglobalisation that refers to certain periods of crisis in which interdependence and integration between countries and peoples around the world are reduced.

One of the events that slowed globalization is the coronavirus pandemic (SARSCoV-2) which started in December 2019. During the pandemic, the four forms of exchange were restricted - the free movement of people, goods, services and capital, which are important drivers of modern globalization. Closing borders, growing protectionism, and severing ties between nations and people were the biggest blow to globalization. But during the pandemic crisis, the information-communication dimension of globalization gained more importance and intensity than before. The power of modern information and communication technology and mass media has proven to be a superior "mass weapon" and an instrument of modern organization and coordination of activities in many aspects. They have contributed to the creation of the "global village" and people, groups and organizations from around the world can follow events, participate together, act and share content in the virtual world (Giddens, 2001). One of the negative consequences is that the media space was used as a means of sharing fake news and disinformation that contributed to distorting the image of reality and real events in the countries and the world. This has caused general insecurity, confusion and social insecurity, as well as divisions among people, and growing dissatisfaction with the way international organizations are run. Informing the public with disinformation and fake news is intended to mislead readers into pursuing political, financial and security interests. Disinformation is "proven false or misleading information created, presented and distributed for economic gain or deliberate deception of the public" (European Commission, 2018). It can harm the public interest, including endangering democratic political processes and public goods such as protecting the health of citizens, environment and security. They are generally led by different actors with different intentions and goals. The most common reason for the spread of disinformation is financial, with an estimated 20,000 disinformation websites generating about $\$ 235$ million a year (Sanders, 2019). 


\section{Fake news and disinformation as a threat to national security}

Two decades ago, it seemed futuristic and unrealistic that global information and communication technologies could lead to fundamental change in societies. Today, things are different, sophisticated technologies are used at the same time, both to encourage and prevent structural changes and activities in countries and societies. This is due to the increasing number of Internet devices (which in 2020 amounted to more than 20 billion devices, which is two and a half times the number of the world's population), which will contribute to the increase in the number of cyber attacks and other types threats arising from the digital-virtual world (The Global Risks Report, 2018:15). In the future, the power of individuals, organizations and nations is expected to come from the use of Internet devices (computers and smart devices) rather than from the power of the "gun barrel". Increased access to the Internet and communication technology has opened the "doors" of people and countries to a global audience, but such openness to the world for many countries, instead of a chance, posed a threat to national security. As a result, most of them banned internet access and social networks nationwide, while other, marginalized dissident groups sought to influence political decisions, but also to establish contact with open societies in which public opinion is a key factor in political decision-making and to cause radical change (Davis and Sweeney, 1999). Information technology (Internet and social networks) has enabled certain groups in the North Africa and Middle East regions to oppose authoritarian regimes and to launch a revolution for a better future. On the other hand, globalization has made modern technologies available to non-state actors, such as terrorists, criminal organizations, antiglobalization movements, hackers who directly threaten national and international security.

There are many examples of the usage of information systems and technologies by states, corporations, groups and individuals to spread fake news and disinformation. Information manipulation has existed for millennia before the advent of modern digital technology. In ancient times, Plato believed that the one who told the truth was in danger of death, and that lies were useful in deceiving the enemy. That is, they were useful as a "medicine handled only by the doctor", and the doctor is the ruler. But at the beginning of the 21st century, the use of disinformation is a weapon of unprecedented proportions. Sophisticated technology has made it easier to manipulate and prepare content, and social media is a powerful source for spreading fake news and disinformation (Ireton and Posetti, 2018). Fake news and disinformation are often used as a substitute for the use of violent means and / or in the "name" of national security, and for initiating military interventions. For example, US manipulation of information related to the Iraq war has left doubts that have long been reflected in their foreign and security policies..$^{41}$ Also in 2014, Russian special forces (without army insignia) entered Ukraine and occupied the main installations in Crimea, and Russian political leaders denied that they were Russian forces, but spontaneously organized selfdefense groups supplied with weapons that looks like Russian in a local store (Harari, 2018). In 2016, social networks were used by pro-Trump spammers from Macedonia (Veles), who

\footnotetext{
${ }^{41}$ According to research by two US nonprofit journalism organizations, the Center for Public Integrity and the Foundation for Independent Journalism conclude that two years after the September 11, 2001 attacks, former US President George W. Bush and his associates (Colin Powell, Donald Rumsfeld, Paul Wolfowitz, Condoleezza Rice, Dick Cheney, etc.) provided 935 inaccurate statements and information about Iraq, related to WMD and al-Qaeda links (Dnevnik, 25 January 2008: 13).
} 
spread fake news and disinformation during the US presidential campaign. The fake news of the Macedonian teenagers generated hundreds of thousands of reactions on the social network Facebook, and they were also featured in the headlines of leading media such as the New York Times, The Washington Post, NBC and others (Silverman and Alexander, 2016). Unlike states that seek to cover up certain information from the public, manipulate information, or classify it as a state secret, there are groups and individuals (such as Edward Snowden, Bradley Manning and Julian Assange ${ }^{42}$ who have leaked a huge amount of confidential materials and classified information to the public. But in practice, anyone who divulges state secrets or shares truthful information in the field of security and defense has always been considered a traitor and a threat to national security, and "messengers were always killed first". In this context, Hannah Arendt believes that "truth and politics are in a rather bad relationship with each other and truth has never been included in political virtue, and lies have been considered a permissible means in politics" (Arendt, 1967).

In conditions of modern globalization where there is unlimited free flow of information and global interconnection, the amount and speed of information transmitted through communication networks is increasing. This means that in the future the intensity of fake news and disinformation that is as harmful to security and stability as conventional warfare will increase. For these reasons, disinformation, propaganda and fake news are referred to as "multimodal threats", or known as hybrid threats, in national security documents of states and international organizations. These threats are a combination of military and non-military means, as well as covert and open means used to blur the line between war and peace, sow suspicion among a population, and aim to destabilize societies (Hoffman, 2007:78).

\section{The use of disinformation during the COVID-19 pandemic}

The coronavirus pandemic has spread to 220 countries and territories and changed the lives of 7.8 billion people worldwide, forcing governments and citizens to adapt to the new unknown situation. The spread of coronavirus outside China has prompted strict measures in many countries of unprecedented proportions, including isolating individuals, closing schools and universities, banning mass gatherings and public events, social distancing, banning travel, imposing quarantine locally or national level, as well as the introduction of a curfew and the declaration of a state of emergency in several countries. These restrictive measures have profoundly affected the national and international economic, social, health and security situation. Since the beginning of the pandemic, more than 3 million people have lost their lives, about 120 million people have fallen into extreme poverty, 255 million jobs have been lost, and approximately 170 million children are out of school. Although the pandemic crisis is not over, the numbers show that the world is facing the worst recession in 90 years (Guterres, 2021).

\footnotetext{
${ }^{42}$ Edward Snowden and Julian Assange sparked a major international scandal when they leaked a huge number of classified documents indicating that there were a number of covert surveillance and wiretapping projects by governments and their services. The international non-profit organization WikiLeaks (founded by Julian Assange) has released millions of classified documents related to the wars in Afghanistan, Iraq, US State Department diplomatic ties and the unethical behavior of governments and organizations.
} 
However, the coronavirus pandemic was followed by an unprecedented information pandemic called "infodemia". This coronavirus-related information was primarily false or inaccurate and quickly spread through social media and platforms such as Facebook, Instagram, Twitter, Snapchat, YouTube, WhatsApp and Reddit, including their Chinese equivalents Weibo, WeChat, Tencent, Tik Tok and Toutiao. Due to the new situation known as "lockdown" in which social contacts were restricted, millions of people were forced to stay at home, which led to more and more people using social networks without checking the facts and the source of information. Given that this is a new virus, which is unknown even to the scientific community and health organizations, it was seen as a fertile ground for spreading fake news and disinformation that caused fear, mistrust and insecurity among the population (European Commission, 2020). This "infodemia" affected the efficiency of the public health system and contributed to the aggravation of the health crisis, which could easily have turned into a security crisis. This was emphasized by the High Representative of the Union for Foreign Affairs and Security Policy, Josep Borrell, who said "Disinformation in times of the coronavirus can kill. We have a duty to protect our citizens by making them aware of false information, and expose the actors responsible for engaging in such practices" (European Commission, 2020).

The complexity of the coronavirus crisis arose from the different theories about the origin of the virus. According to the World Health Organization, the coronavirus originated from a bat at a food market in the city of Wuhan, in the Chinese province of Hubei, while senior US officials claimed that the virus originated in a laboratory in Wuhan.Then the mass media began to criticize the Chinese for consuming live animals (bats, dogs, snakes, etc.), so hatred and revolt against the Chinese nation began to spread. On the other hand, strained trade relations between the United States and China, as well as US accusations that the Chinese technology company Huawei is a cover for Chinese espionage and a threat to national security, have contributed to the coronavirus issue being politicized and used to pursue national security interests. The coronavirus crisis situation was further intensified when the United States/ntelligence Community $(I C)$ releasedthe latest information about the origin of the coronavirus, which confirmed that the virus appeared naturally, i.e. through human contact with infected animals, or a possible consequence of a laboratory accident in Wuhan(ODNI Statement on COVID-19 Origins, 2021). The Chinese Ministry of Foreign Affairs opposed the intelligence information, noting that US laboratories were also suspicious and needed to be investigated.

As the number of infected and dead people increased, disinformation and fake news intensified day by day. Microsoft philanthropist and co-founder Bill Gates has become a leading target in pandemic conspiracy theories, especially as he criticized former US President Donald Trump's decision to cut funding and withdraw from the World Health Organization (WHO), which was accused by the United States of mismanaging the pandemic and covering up evidence of coronavirus spread (BBC, 7 July 2020). In addition, Gates's speeches(from 2015) were shared on social media warning that the greatest threat to humanity is not nuclear war, but an infectious virus that could endanger the lives of millions (Gates, 2015). He gave a similar speech at the Munich Security Conference in 2017, noting that "there is a threat of bioterrorism where terrorists could create a synthetic version of a virus that could kill an estimated 30 million peoplein less than a year" and that the world is likely to experience an epidemic in the next 10 to 15 years.According to him, the irony is that the cost of providing adequate preparedness for a global pandemic is estimated at 3.4 billion dollars 
a year, while the annual loss that could cause a pandemic could reach 570 billion dollars. For those reasons, he called on countries to invest in research and develop technologies that could produce a vaccine for several months. The philanthropist, who has been funding the global health campaign for more than 20 years, said: "We ignore the link between health security and international security at our peril" (Gates, 2017). In a short period of time, these speeches became among the most viewed and shared on social networks by anti-globalists, anti-vaxxers, anti-pharmaceutical groups and members of conspiracy and public manipulation groups, who used the videos as proof that one of the richest people in the world planned to use the pandemic to control the global health system. ${ }^{43}$ Among other things, disinformation has been spread that the billionaire will want to implant microchips in the global population through the vaccination process, which will establish complete control over it or an attempt at depopulation by endangering human health.

Furthermore, the fear and anxiety of a part of the population increased when disinformation spread about the connection between the coronavirus crisis and $5 \mathrm{C}$ technology. In fact, disinformation has been spread in the public that the virus is not to blame for the current pandemic, but electromagnetic radiation of $5 \mathrm{C}$ technology, and that was one of the main reasons why citizens do not use protective masks. Fake news and disinformation about this conspiracy theory have led to the demolition and destruction of mobile phone towers in some countries, due to allegations that the $5 \mathrm{C}$ network caused the coronavirus pandemic or spread the virus. Quarantines and curfews have also been criticized for allegedly secretly installing $5 \mathrm{C}$ technology, despite expert explanations that there is no link between the virus and the technology. The intensity of disinformation was increased, especially in the Western Balkan countries, where the blame for the installation of 56 technology shifted to the NATO alliance, which is considered the protector of modern globalization. At the same time, disinformation and propaganda were spread by Russian hackers and anti-Western websites that NATO laboratories, or US troops, had created the coronavirus as a biological weapon. In addition, fake videos were posted on social networks as planes (allegedly owned by the WHO or NATO) spraying a solution that causes the symptoms of the coronavirus. This has intensified the rivalry between the greatpowers in the field of cyber security, the fight against disinformation and other "geopolitical games"(Sabbagh, 2020).

At times, the health crisis escalated into a security crisis. The rising number of coronavirus infections and deaths has not prevented thousands of citizens from expressing their dissatisfaction with mass protests in many Western countries that are at the forefront of modern globalization. The dissatisfaction referred to the non-transparency, restrictive measures and protocols and the unpreparedness of national governments and international organizations in dealing with the global pandemic. Namely, with the spread of the pandemic, the "infodemia" was growing in parallel, which was as dangerous as the coronavirus, especially when the development and distribution of vaccines began. Fake news and disinformation

\footnotetext{
${ }^{43}$ According to CNBC, conspiracy theories falsely linking Bill Gates to the origins of the coronavirus have been mentioned 1.3 million times on television and social media from February to April 2020, which is $33 \%$ more than any other popular pandemic conspiracy theory with 56 technology. In just one day, Gates and coronavirus-related disinformation has been mentioned more than 18,000 times in the mass media, while over the past year, more than 16,000 disinformation posts have been shared on Facebook that have been liked and commented on about 900,000 times (Huddleston, 2020).
} 
affected the public perception of the quality of vaccines (side effects of vaccinated), but also about the production and delivery of vaccines (UNICEF, 2021). Thus, the pressure on the public increased and new divisions were created (of vaxxers and anti-vaxxers, of globalists and antiglobalists, of traditionalists and modernists) and misunderstandings among the population about which vaccine (American, Russian, Chinese or British-Swedish vaccine) is better for human health.The spread of disinformation about vaccines has also been contributed by well-known influencers (who have a huge number of followers on social networks), who are believed to have received large sums of money to spread lies and propaganda about the consequences of some of the vaccines.It created additional fear and panic among the population, and increased rivalry between certain groups, without first realizing and checking the scientific facts about the possible implications of the vaccines. Regionally and globally, coronavirus vaccines have been used as a "geopolitical weapon", or "non-military conquest of the world", further straining East-West relations.

According to the representative Global Disinformation Index (GDI), disinformation sites related to Covid-19 aim to:

1.Harm to specific groups

a) Conspiracy theories on origin of the pandemic.

b) Minorities more susceptible / take less precautions / spread it more.

c) Anti WHO.

2.Harm to public order

a) Lockdown protests.

b) Virus as population control.

c) Attacks on $5 \mathrm{G}$ masts and engineers.

3. Harm to public health
a) Anti covid vaccination.
b) Bunk cures.
c) Anti facemasks (Global Disinformation Index, 2020).

In general, "infodemia" has forced people to ignore official health advice and engage in risky behavior that could adversely affect democratic governance and the socio-economic and security situation of states and societies. For these reasons, international organizations (such as the EU, NATO, UN, WHO) have stepped up their activities and started developing strategies, action plans and initiatives to combat fake news and disinformation. One of the most important global initiatives is the "Cross-Regional Statement on "Infodemic"in the Context of COVID-19" which is signed by 132 UN member states. The aim of the initiative is to create a healthy informationand security environmentat national, regional and global levels and to counteract the "infodemia" with the help of scientific evidence and verified facts (CrossRegional Statement on "Infodemic" in the Context of (OVID-19).

\section{Conclusion}

The coronavirus pandemic has accelerated the process of deglobalization seen in declining world trade, deepening inequality, rising debt, the dysfunction of national governments and international crisis management organizations, and declining multilateral cooperation between nations. During the pandemic crisis, the power of digital technology was used by various 
actors to distribute fake news and disinformation that contributed to the deteriorating health and security situation in the states. To a large extent, disinformation has polarized societies on a variety of grounds, negatively impacting stability and tackling the global pandemic. Therefore, we have a responsibility, but also a duty as representatives of the scientific community to influence through participation in public debates, to publish academic research and scientific theories in order to combat fake news and disinformation. In addition to the scientific community, official institutions, academic publishers and university libraries are a reliable source of knowledge, facts and empirical evidence, they are of paramount importance in combating disinformation. States and international organizations should also strive for new legislation, penalties and other forms of control mechanisms for digital platforms and social media that publish fake news, illegal content and sow hate speech.

\section{References:}

1. Anwar, A et al. (2020). "Role of Mass Media and Public Health Communications in the COVID-19 Pandemic". Cureus vol. 12 (9): e10453. Available at: https://www.ncbi.nlm. nih.gov/pmc/articles/PMC7557800/, accessed on 23/2/2021.

2. Arendt, H. (1967). Truth and Politics: Political theory and social change. Atherton Press, New York.

3. Assange, J.(2011). The unauthorized autobiography. Canongate Books, Edinburgh.

4. Borger,J. (2014): "Putin offers Ukraine olive branches delivered by Russian tanks", Guardian, March 4. Available at:https://www.theguardian.com/world/2014/mar/ 04/ putin-ukraine-olive-branches-russian-tanks, accessed on 4/4/2021.

5. "Coronavirus: Trump moves to pull US out of World Health Organization", BBC, 7 July 2020. Available at: https://www.bbc.com/news/world-us-canada-53327906, accessed on $28 / 4 / 2021$.

6. "Cross-Regional Statement on "Infodemic" in the Context of COVID-19". Available at:https://onu.delegfrance.org/IMG/pdf/cross-regional statement on infodemic final with all endorsements.pdf, accessed on 4/5/2021.

7. Davis, K.J. and Sweeney, J.M. (1999). Strategic Paradigms 2025: U.S. Security Planning for a New Era. Institute for Foreign Policy Analysis, Brassey's.

8. European Commission (2020). Coronavirus: EU strengthens action to tackle disinformation, 10 June Brussels. Available at:https://ec.europa.eu/commission / presscorner/detail/en/ip 20 1006, accessed on 14/12/2020.

9. European Commission (2020).Tackling COVID-19 disinformation - Getting the facts right. Brussels. Available at:https://eur-lex.europa.eu/legal-content/EN/TXT/?uri= CELEX:52020JC0008,accessed on 9/2/2021.

10. European Commission (2018). EU Code of Practice on Disinformation. Brussels. Available at:file:///C:/Users/DELL/AppData/Local/Temp/final eu code of practice on 
disinformation D338C8F1-A97F-2907-656993A02EFA92BA_54454.pdf, accessed on $17 / 1 / 2021$.

11. Gates, B.(2017): "Speech by Bill Gates at the 53rd Munich Security Conference 2017", Munich Security Conference, February 18. Available at:, accessed on 17/11/2018.

12. Gates, B.(2015):"The next outbreak? We're not ready", YouTube, Apr 3.Available at:https://www.youtube.com/watch?v=6Af6b wyiwl, accessed on 13/11/2020.

13. Giddens, A.(2001). Sociology (4th edition). Polity, Cambridge.

14. Global Disinformation Index (2020). "Ad funded Covid-19 Disinformation:Money, Brands and Tech", GDI, 8 July. Available at:https://www.isba.org.uk/system/files/ media/documents/2020-12/gdi ad-funded-covid-19-disinformation-1.pdf, accessed on $21 / 12 / 2020$.

15. Guterres, A. (2021)."Remarks to the 2021 Economic and Social Council Forum on Financing for Development", 12 April. The United Nations. Available at:https:// www.un.org/sg/en/content/sg/speeches/2021-04-12/remarks-2021-ecosoc-forumfinancing-for-development $\% \mathrm{C} \% \mathrm{~A} 0$, accessed on 16/4/2021.

16. Harari, N.Y. (2018). 21 Lessons for the 21st Century.Jonathan Cape.

17. Hoffman, F.G. (2007). Conflict in the 21 ${ }^{\text {st }}$ century: the rise of hybrid wars, Potomac Institute for Policy Studies, Arlington, Virginia.

18. Huddleston,T.Jr. (2020): "Bill Gates is the top target for coronavirus conspiracy theories",Make It, 17 April. Available at:https://www.cnbc.com/2020/04/17/billgates-is-top-target-for-coronavirus-conspiracy-theories-report.html, accessed on $7 / 4 / 2021$.

19. Ireton, C. andPosetti, J. (2018). Journalism, "Fake news" \& Disinformation: Handbook for Journalism Education and Training.UNESCO, Paris.

20. Micklethwait, J. and Wooldridge, A. (2014). The fourth revolution: the global race to reinvent the state. The Penguin Press, New York.

21. "ODNI Statement on COVID-19 Origins". Office of the Director of National Intelligence, May 27, 2021. Available at:https://www.dni.gov/index.php/newsroom/press-releases/ press-releases-2021/item/2218-odni-statement-on-covid-19-origins, accessed on 28/05/2021.

22. Popovic, T.G. (2003). Globalisation crisis and/or Crisis globalisation. Besjeda, Banja Luka.

23. Robertson, R. and White, E. Kathleen (2007). What is Globalisation? In: Ritzer, George (Ed.) The Blackwell Companion to Globalization. Oxford: Blackwell.

24. Sabbagh, D.(2020): "Russia-aligned hackers running anti-Nato fake news campaign - report", Guardian, 30 July.Available at:https://www.theguardian.com/ 
technology/2020/jul/30/russia-aligned-hackers-running-anti-nato-fake-newscampaign-report-poland-lithuania, accessed on 26/11/2020.

25. Sanders, L.(2019): “Disinformation sites generate over $\$ 200$ million: study",Deutsche Welle, 22 September.Available at:https://www.dw.com/en/disinformation-sitesgenerate-over-200-million-study/a-50537297,accessed on 23/12/2020.

26. Silverman,C. and Alexander, L. (2016): "How Teens In The Balkans Are Duping Trump Supporters With Fake News",BuzzFeed News, November 3. Available at:https://www. buzzfeednews.com/article/craigsilverman/how-macedonia-became-a-global-hub-forpro-trump-misinfo, accessed on 7/5/2021.

27. Steger, M.B. (2003).Globalisation. Oxford University Press, New York.

28. UNICEF (2021). Information on quality, distribution and safety of COVID-19 should be taken from trusted, science-based sources only, 17 March.Available at:, accessed on $8 / 5 / 2021$.

29. World Economic Forum (2018).The Global Risks Report 2018, 13th Edition. World Economic Forum, Geneva. Available at:http://www3.weforum.org/docs/WEF GRR18 Report.pdf, accessed on 19/6/2020. 